\title{
Work-Related Values in International Workplaces in Vietnam: Cross-Cultural Differences between Employers and Employees
}

\author{
Tran Thien Quynh Tran ${ }^{1,2}$, Wilfried Admiraal'2, Nadira Saab ${ }^{2}$ \\ ${ }^{1}$ Can Tho University of Technology, Can Tho, Vietnam \\ ${ }^{2}$ Graduate School of Teaching (Iclon), Leiden University, Leiden, The Netherlands \\ Email: ttqtran@ctuet.edu.vn
}

How to cite this paper: Tran, T. T. Q., Admiraal, W., \& Saab, N. (2020). WorkRelated Values in International Workplaces in Vietnam: Cross-Cultural Differences between Employers and Employees. Open Journal of Business and Management, 8, 1567-1586. https://doi.org/10.4236/ojbm.2020.84100

Received: June 9, 2020

Accepted: July 11, 2020

Published: July 14, 2020

Copyright $\odot 2020$ by author(s) and Scientific Research Publishing Inc. This work is licensed under the Creative Commons Attribution International License (CC BY 4.0).

http://creativecommons.org/licenses/by/4.0/

\begin{abstract}
With the trends in globalization and internationalization, cross-culture work-related values are increasingly receiving attention of both managers and researchers. This study aimed to investigate the cultural differences in work-related values between Western managers and Vietnamese employees in Vietnam. In two areas in the South of Vietnam, 94 Western and Vietnamese companies participated with 763 Vietnamese employees, 43 Vietnamese employers and 33 Western employers who have completed a questionnaire. In addition, semi-structured interviews were administered with 11 Western employers and 33 Vietnamese employees to validate the findings from the questionnaire data. Significant differences in work-related values between Western employers and Vietnamese employees were found. Time perception and face-concern were found to be the two largest differences between Western and Vietnamese professionals. Implications are discussed for further training of Vietnamese prospective graduates.
\end{abstract}

\section{Keywords}

Western Higher Employers, Vietnamese Employees, Work-Related Values, Cultural Differences, Intercultural Communication

\section{Introduction}

In recent years, the economy in Vietnam has gone through a transitional development. For a long time, Vietnamese culture has been influenced by Confucianism, which comprises high collectivism, large power distance, high uncertainty avoidance, masculinity and long-term orientation (Vuong, 2002). After the eco- 
nomic reform "Doi Moi" (1986), the Vietnamese government provoked the country's economic activities through transforming state owned enterprises, boosting private businesses and appealing foreign direct investment (Weng, 2015). This transfer brought to the economy both universal practices and international managers because the current personnel were not seen as qualified enough to keep pace with the new trend (Weng, 2015). As foreign companies were mushrooming in the country, the call for more industry prospective graduates increased. Yet new graduates in Vietnam are ill-prepared for working in a multicultural context (Tran, 2013; Tran, 2015), even though most of these new workers are supposed to work in multinational organizations. Insights are needed on how to improve the communication between Western higher managers and the host-national employees as well as to provide input for higher education educators to adapt their programs to support the prospective graduates in the development of intercultural communication skills at the workplace. Therefore, in the current study, we examine work-related values of Vietnamese and Western professionals to better understand what type of communication issues come about when professionals from the two different cultures, Western and Vietnamese, work side by side.

In the present study, we aimed to investigate the differences between employees and employers of Vietnamese and Western companies in terms of their work-related attitudes in order to get an in-depth look into the challenges and problems that these professionals face in their daily work in an intercultural context in Vietnam. We elaborated on the concepts of "work-related values" and based on these values, we carry out the research to determine the values that could affect the communication and relationships between Western employers and Vietnamese employees in foreign subsidiaries and joint-ventures. Holding an insightful view of the differences between employers and employees from different cultural backgrounds in organizations in Vietnam could improve Vietnamese international workplace environment as well as assist higher education institutions in designing further cross-cultural training curriculum.

\section{Work-Related Values}

Work-related values can be understood as goals that one seeks in work to attain to satisfy a need and are manifested in differences in individual performance, predicting job satisfaction and a committed workforce (Matic, 2008). Accordingly, in a cross-cultural context, work-related values are significant factors that affect negotiations and communication at work, and leadership and management styles. Previous studies about intercultural communication in the workplace in Vietnam (Pham, 2012; Truong \& Nguyen, 2002) have just touched one or two cultural dimensions of work-related values. Based on the framework of Hofstede (Hofstede, 2001; Hofstede \& Bond, 1988; Kirkman, Bradley, Kevin, \& Cristina, 2006) and documentation of Vietnamese Confucian culture (Truong, Hallinger, \& Sanga, 2017; Ngyuen, 2015), we have identified six cross-cultural 
work-related values.

\section{Sense of time}

Sense of time is the way people feel, experience and evaluate time (Venter, 2006). Time and punctuality were differently treated in different cultures. Many researchers have conceptualized the difference in time perception between Western and Eastern culture which has influenced professionals' manners, decisions and expectations in a cross cultural workplace. Wang, Wang, Ruona \& Rojewski (2007) argued that people in Confucian cultures like Chinese and Vietnamese tend to orient more towards the past than to the present and future. This means that time in those cultures is considered flexible and repeatable and is used to achieve eventual human reward. This perspective conveys a reverse orientation with Western culture, which accentuated efficiency and time in order to achieve personal and organizational goals (Arman \& Adair, 2012).

\section{Power distance}

The concept of power distance can be interpreted as the degree to which individuals feel comfortable with an unequal distribution of power and how much of an equal distribution they expect and find acceptable (Hofstede, 2001). With respect to the concept of power, three work-related values can be distinguished.

Taking part in management's decision making relates to the degree employees that have a voice in work-related decisions. Cultural values, and power distance in particular, might highly affect the degree of employee participation in work-related decisions (Le, Rowley, Truong, \& Warner, 2007). In Vietnamese culture, people endeavor to share group goals and employees might be hesitant to involve their own voice in the process of higher management' decision-making even if they are demanded to do so (Le, Rowley, Truong, \& Warner, 2007). In contrast, Western culture underscores an individual's thoughts and opinions, initiative and achievement and individual decision-making (Wang et al., 2007).

Open relationship with higher managers is operated by the degree of power distance the employees perceive towards their higher managers. The more power from the employers the employees observe, the more distance they feel. According to Diem (2013), He \& Liu (2010) and Wang (2009), in low-power distance countries, the distribution of authority is exercised and authority figures have a closer relationship with their subordinates. However, in a hierarchical country like Vietnam, more formal employer-employee relationship is acknowledged than compared to low power distance countries (Sagie \& Aycan, 2003).

Leadership at the workplace refers to a third work-related value. Being influenced by Confucianism, authoritarian leadership is commonly seen in Vietnamese organizational culture (Le et al., 2007). In this kind of leadership, the managers usually show their power over their employees and the decisions are often made by the management. In contrast, work-performance orientated leadership can be defined as "the degree to which a collective encourages and rewards group members for performance improvement and excellence" (House, Javidan, \& Dorfman, 2001). In Western culture, autonomy and individual initiative are 
encouraged and the employees have more freedom to take their actions in the workplace context (Weng, 2015).

\section{Face-concern}

Jariya (2012) and Pham (2014) defined face-saving as people's recognition of face preservation to prevent social disapproval or criticism, not only for themselves but also the community they belong to. Scholars have consistently pointed out that face protection is of utmost significance in most Eastern cultures (Kim \& Nam, 1998). This means that the focus is placed on reaching a consensus within organizations in order to save mutual face and maintain harmony. Because of this, the Vietnamese employees tend to avoid talking when it comes to negative issues; the listeners have to read between the lines what the real meaning is (Bjorkman \& Lu, 1999). In contrast, face concern in Western culture implies the individual's want to be approved of and the individual's want to be free from imposition (Pham, 2014). In fact, in Vietnamese culture, face is determined by hierarchical social status and harmonious relationship with other people, whereas in Western culture, face is determined by the individual's internal attributes such as competence and skills. Accordingly, for the sake of face concern, indirect communication tends to be used by Vietnamese employees, which might cause ambiguity and misunderstandings to Western professionals.

\section{Accountability}

Gelfand, Lim \& Raver defined accountability as "the perception of being answerable for actions or decisions, in accordance with interpersonal, social, and structural contingencies, all of which are embedded in particular sociocultural contexts" (Gelfand, Lim, \& Raver, 2004: p. 137). In individualistic culture, individuals are normally accountable for both individual and organizational successes or failures, whereas in collectivistic culture, the group's successes or failures are often counted on the groups or the community. The Vietnamese culture bears this specific trait of collective responsibility in which people identifying themselves as part of a specific group, team or unit and individual accountability is not clearly defined (Bjorkman \& Lu, 1999).

The current study, differences between employees and employers of Vietnamese and Western companies were examined in terms of their work-related values. We aimed to answer the following question:

"To what extent do Vietnamese employees and Western employers differ with respect to their work-related values?"

We formulated three hypotheses:

1) Western employers will report significantly different scores on the work-related values of sense of time, taking part in decision-making, open relationship with employers, leadership, face concern and accountability, compared with both Vietnamese employees and Vietnamese employers;

2) Vietnamese employers and employees will report less strong differences in these work-related values; and

3) Vietnamese employees in Vietnamese companies and Vietnamese employees in foreign companies will not report significant differences in these work-related 
values.

\section{Method}

In the current study, a mixed method design is used. A survey was conducted to obtain the participants' perceptions and preferences towards the selected work-related values. Afterwards, semi-structured interviews were employed to validate and illustrate the data from the survey.

\section{Participants}

In total, participants from 94 Western and Vietnamese companies in two areas in the South of Vietnam (Ho Chi Minh City and the Mekong Delta) joined in the study. We looked for the companies' information on the Internet, using reports on the Global Trade in Customer Language website (http://eu.ecizi.com). We also searched for companies using the researchers' networks. We visited 128 companies, and 94 of them agreed to participate. Of these 94 companies, 47 were foreign subsidiaries and joint-ventures and 47 were Vietnamese private and state companies. In 47 foreign companies, 33 higher managers (all Westerners including Americans, Australians, New Zealanders, and Europeans) and $360 \mathrm{Vi}$ etnamese employees participated. In 47 Vietnamese companies, 43 Vietnamese higher managers and 403 Vietnamese employees participated. In the next phase, 21 Western companies agreed to participate in the qualitative interview study. This resulted into the participation of 11 Western employers/managers (10 males, age range 28 - 55 years of age and at least two years experience managing Vietnamese employees) and 33 Vietnamese employees (30 females, age range 20 - 45 years of age and 1 to 10 years experience working in a foreign company) working in foreign subsidiaries and joint-ventures in Ho Chi Minh city. We provide background information on employees and employers in Table 1 and Table 2, respectively.

\section{Data collection}

Data have been collected with a questionnaire and interviews. One of the researchers visited each company in person to deliver the paper questionnaires and provided instructions to do the questionnaires, in which the participants were asked to rate their "Preferences" for the questionnaire items. The level of the preferences ranges from "not at all", "not really", "somewhat", "quite a lot" to "very much" and the participants have to choose the option that is appropriate to their situation. In some companies, the participants answered the questionnaires with the researcher's instructions; in others, due to time constraints, they answered the questionnaires by utilizing an instructional guideline delivered to the companies' secretary. Statements of participants' implied consent were included in the instrument. Vietnamese employers and employees received a Vietnamese version of the questionnaire, whereas Western employers completed an English version.

After administering the questionnaires, the semi-structured interviews were conducted to explore further what and how professionals from two cultures 
Table 1. Background information of Vietnamese employees (number of participants).

\begin{tabular}{|c|c|c|}
\hline Background Information & Vietnamese companies & Western companies \\
\hline \multicolumn{3}{|l|}{ Age } \\
\hline$<18$ & 0 & 0 \\
\hline $18-29$ & 158 & 125 \\
\hline $30-39$ & 127 & 119 \\
\hline $40-49$ & 22 & 17 \\
\hline 50 or older & 4 & 1 \\
\hline \multicolumn{3}{|l|}{ Gender } \\
\hline Male & 95 & 77 \\
\hline Female & 216 & 183 \\
\hline \multicolumn{3}{|l|}{ Years of working in Vietnam } \\
\hline $1-2$ years & 35 & 23 \\
\hline $3-5$ years & 91 & 73 \\
\hline More than 5 years & 71 & 55 \\
\hline 10 years & 28 & 46 \\
\hline More than 10 years & 69 & 61 \\
\hline More than 20 years & 17 & 5 \\
\hline \multicolumn{3}{|c|}{ Years of working with Non-Vietnamese } \\
\hline $1-2$ years & 88 & 86 \\
\hline $3-5$ years & 64 & 80 \\
\hline More than 5 years & 28 & 71 \\
\hline 10 years & 2 & 8 \\
\hline More than 10 years & 9 & 9 \\
\hline More than 20 years & 2 & 1 \\
\hline \multicolumn{3}{|l|}{ Highest degree } \\
\hline Elementary & 0 & 0 \\
\hline Secondary & 1 & 0 \\
\hline High school & 5 & 0 \\
\hline Vocational & 10 & 17 \\
\hline College/University & 273 & 228 \\
\hline Other & 22 & 15 \\
\hline
\end{tabular}

Table 2. Background information of Vietnamese and western employers (number of participants).

\begin{tabular}{ccc}
\hline Background Information & Vietnamese companies & Western companies \\
\hline Age & 0 & 0 \\
$<18$ & 0 & 0 \\
\hline
\end{tabular}




\section{Continued}

\begin{tabular}{|c|c|c|}
\hline $18-29$ & 8 & 3 \\
\hline $30-39$ & 25 & 17 \\
\hline $40-49$ & 8 & 13 \\
\hline 50 or older & 2 & 0 \\
\hline \multicolumn{3}{|l|}{ Gender } \\
\hline Male & 19 & 30 \\
\hline Female & 23 & 3 \\
\hline \multicolumn{3}{|l|}{ Job status } \\
\hline $\mathrm{CEO}$ & 3 & 9 \\
\hline Deputy CEO & 0 & 4 \\
\hline Senior manager & 6 & 4 \\
\hline Middle manager & 3 & 8 \\
\hline First-line manager & 17 & 6 \\
\hline Supervisor & 14 & 1 \\
\hline \multicolumn{3}{|l|}{ Years of working in Vietnam } \\
\hline $1-2$ years & 1 & 4 \\
\hline $3-5$ years & 0 & 13 \\
\hline More than 5 years & 11 & 10 \\
\hline 10 years & 4 & 2 \\
\hline More than 10 years & 21 & 4 \\
\hline More than 20 years & 6 & 0 \\
\hline \multicolumn{3}{|l|}{ Highest degree } \\
\hline Elementary & 0 & 0 \\
\hline Secondary & 0 & 0 \\
\hline High school & 0 & 0 \\
\hline Vocational & 0 & 0 \\
\hline College/University & 35 & 26 \\
\hline Other & 8 & 7 \\
\hline \multicolumn{3}{|l|}{ How large is the organization? } \\
\hline Micro (<10 employees) & 5 & 1 \\
\hline Small (<50 employees) & 9 & 14 \\
\hline Medium-sized (<250 employees) & 13 & 11 \\
\hline Large (>250 employees) & 11 & 6 \\
\hline
\end{tabular}

experienced work-related values. The first author visited the companies to ask for permission to conduct the interviews. The interview took about thirty minutes to one and a half hour for each participant. Notes were taken during and after the interviews to retain any insights gained or questions raised. Any 
follow-up inquiries were done by phone calls or emails to the respondents.

\section{Instruments}

\section{Questionnaire}

Based on the literature on work-related values a questionnaire has been developed with items referring to 1 ) what the employers expect from their employees and vice versa and 2) how important the issues (policies in the company) are for both the employers and employees. Items were scored on a 5-point Likert type scale with " $1=$ not at all", " $2=$ not really", " $3=$ somewhat", " $4=$ quite a lot", " 5 = very much". The questionnaire was designed in English and then translated into Vietnamese. We employed a back translation to ensure the validity of the translation. The questionnaire was piloted with one foreign and one Vietnamese company.

In order to explore underlying dimensions, we performed an exploratory factor analysis on the employees' questionnaire data (using Principle component analysis and Varimax rotation), separately on the expectation and importance questionnaire items. We decided for four factors for the expectation items, based on the elbow criterion, explaining $48 \%$ of the variance between employees. Items with factor loadings $>0.4$ on one factor and $<0.4$ on the other factors were included; all other items were excluded. We repeated this analysis procedure for the important items, which resulted in one underlying factor, explaining 52.3\% of the total variance. We then performed reliability analyses on these five factors and subdivided the "sense of time" factor into two sub-factors named "being on time in a direct way" and "being on time with a condition". Similarly, the "power distance" factor was split into two sub-factors labelled "taking part in decision-making" and "open relationship with higher managers". This procedure resulted in seven work-related values, which are summarized in Table 3.

Table 3. Seven work-related values as measured in the questionnaire.

\begin{tabular}{|c|c|c|}
\hline Value & Description & Example item \\
\hline Being on time in a direct way & $\begin{array}{l}\text { The extent to which employers and employees evaluate the degree } \\
\text { of punctuality in daily work situations }\end{array}$ & Being late for meeting at work \\
\hline $\begin{array}{l}\text { Being on time with a } \\
\text { condition }\end{array}$ & $\begin{array}{l}\text { The extent of punctuality the employers and employees evaluate } \\
\text { in daily work situations, but with a condition added }\end{array}$ & $\begin{array}{l}\text { Asking for a deadline extension if I have good } \\
\text { reasons }\end{array}$ \\
\hline $\begin{array}{l}\text { Taking part in } \\
\text { decision-making }\end{array}$ & $\begin{array}{l}\text { The extent to which decision-making between higher managers } \\
\text { and employees in daily work situations is shared }\end{array}$ & $\begin{array}{l}\text { Being consulted before the employers/higher } \\
\text { managers' decisions are made }\end{array}$ \\
\hline $\begin{array}{l}\text { Open relationship with higher } \\
\text { managers }\end{array}$ & $\begin{array}{l}\text { The degree of intimacy or closeness in daily communication in } \\
\text { the workplace between employers and employees }\end{array}$ & Talking freely to higher managers \\
\hline Accountability & $\begin{array}{l}\text { The extent to which self-accountability in their daily work } \\
\text { situations is performed by the employees and employers evaluate } \\
\text { and control their employees' accountability in these situations }\end{array}$ & $\begin{array}{l}\text { Being kept responsible for the quality of the } \\
\text { work that I produce }\end{array}$ \\
\hline Face concern & $\begin{array}{l}\text { The extent to which employees save their face in order to keep } \\
\text { their own and others' prestige in daily work situations }\end{array}$ & $\begin{array}{l}\text { Withdrawing my point of view instead of } \\
\text { encountering my employers/higher managers }\end{array}$ \\
\hline $\begin{array}{l}\text { Autocratic versus } \\
\text { work-performance orientation }\end{array}$ & $\begin{array}{l}\text { The extent to which how employees' work-performance is } \\
\text { controlled and evaluated by their higher managers }\end{array}$ & $\begin{array}{l}\text { Promotion on the basis of my actual } \\
\text { contribution }\end{array}$ \\
\hline
\end{tabular}


After establishing the seven factors of work-related values for Vietnamese employees, we employed this structure on the employers' data. In Table 4, we included for each work-related value the number of items and the reliability in terms of Cronbach's alpha.

\section{Interviews}

The interviews were semi-structured with two introduction questions, one main question and four follow-up questions. All the questions were employed to assist the participants to relate their experiences comprising of 1) their interests when working in the current company, 2) their opinions about intercultural communication with their cross-cultural counterparts, 3) the problems or incidents they faced during the interactional process, what was done and how they fixed the problems and 4) their expectations from their cross-cultural partners. Interviews were summarized per interview question by the first authors, based on her notes during the interviews.

\section{Data analysis}

First, we have recoded the items on face concern so that the higher the score, to meet the expected directions of the other work-related values. This means that the higher the scores on face concern, the lower the face concern. Then, we calculated the correlations between the seven work-related values (see Table 5). As might be expected after factor analyses with varimax rotation, the correlations between the seven work-related values are low to moderate. In order to answer the research question, multivariate analyses of variance were performed with two groups of participants as factor and the seven work-related values as dependent variables. In the analyses, the two groups of participants differed based on the hypothesis: Western employers and Vietnamese employees, and Western and Vietnamese employers (hypothesis 1), Vietnamese employers and Vietnamese employees (hypothesis 2), and Vietnamese employees from Western companies and form Vietnamese companies (hypothesis 3 ).

The participants' answers in the interview transcriptions were sorted using six work-related values, similar as in the questionnaire: 1) sense of time, 2) participation in decision-making, 3) open relationship with employers/managers, 4)

Table 4. Work-related values from the questionnaire data for employees and employers.

\begin{tabular}{|c|c|c|c|c|c|}
\hline & \multicolumn{2}{|c|}{ Number of items } & \multicolumn{3}{|c|}{ Cronbach $\alpha$} \\
\hline & Employees & Employees & Vietn. employees & Vietn. employers & Western employers \\
\hline \multicolumn{6}{|l|}{ Work-related value } \\
\hline Being on time in a direct way & 4 & 4 & 0.68 & 0.65 & 0.83 \\
\hline Being on time with a condition & 3 & 3 & 0.79 & 0.81 & 0.80 \\
\hline Open relationship with employers & 9 & 8 & 0.85 & 0.60 & 0.83 \\
\hline Accountability & 4 & 3 & 0.75 & 0.77 & 0.86 \\
\hline Face concern & 4 & 4 & 0.69 & 0.61 & 0.80 \\
\hline Work performance vs autocratic orientation & 9 & 9 & 0.85 & 0.67 & 0.85 \\
\hline
\end{tabular}

Note. Vietn. $=$ Vietnamese 
Table 5. Correlations between the seven scales referring to work-related values.

\begin{tabular}{cccccccc}
\hline & 1 & 2 & 3 & 4 & 5 & 6 & 7 \\
\hline 1 & & $0.412^{* * *}$ & $-0.141^{* * *}$ & $-0.090^{*}$ & -0.034 & $0.080^{*}$ & -0.069 \\
2 & $0.269^{*}$ & & $-0.256^{* * *}$ & $-0.241^{* * *}$ & $-0.237^{* * *}$ & 0.050 & $-0.145^{* * *}$ \\
3 & -0.006 & $0.248^{*}$ & & $0.584^{* *}$ & 0.025 & $0.228^{* * *}$ & $0.321^{* * *}$ \\
4 & $0.504^{* * *}$ & -0.039 & 0.211 & & $0.144^{* * *}$ & $0.266^{* * *}$ & $0.402^{* * *}$ \\
5 & $0.585^{* * *}$ & -0.007 & -0.121 & $0.511^{* * *}$ & & $-0.207^{* * *}$ & 0.014 \\
6 & $0.422^{* * *}$ & $0.656^{* * *}$ & $0.378^{* * *}$ & 0.183 & 0.171 & & $0.197^{* * *}$ \\
7 & $0.334^{* *}$ & -0.10 & 0.142 & $0.337^{* *}$ & $0.283^{*}$ & 0.155 & \\
\hline
\end{tabular}

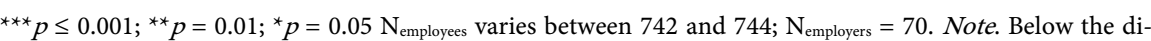
agonal for employers, above the diagonal for employees $(1=$ Being on time in a direct way, $2=$ Being on time with a condition; 3 = Taking part in decision-making, $4=$ Open relationship with employers/managers, $5=$ Accountability, $6=$ Face concern and $7=$ Work-performance orientation vs autocratic orientation).

face-concern, 5) accountability and 6) work-performance orientation. Interview data are used to illustrate the findings from the analyses of the quantitative questionnaire data.

\section{Results}

In Table 6, the means and standard deviations on the seven work-related values are presented for each of the four groups of participants.

Work-related values of Western employers, Vietnamese employers and Vietnamese employees

To test the first hypothesis, two multivariate analyses of variance have been carried: one with Western employers and Vietnamese employees as group, and one with Western employers and Vietnamese employers as group. From the first multivariate analysis, we see that Western employers showed significantly higher scores on work-related values (Wilks' $\lambda(7,56)=57.885 ; p \leq 0.001 ; \eta^{2}=0.879$ ), compared to Vietnamese employees. The test of between-subjects effects indicated that both groups differed significantly on all seven work-related values with higher scores for Western employers on Being on time in a direct way $(\mathrm{F}(1,63)$ $\left.=212.712 ; p \leq 0.001 ; \eta^{2}=0.774\right)$, Being on time with a condition $(\mathrm{F}(1,63)=20.788$; $\left.p \leq 0.001 ; \eta^{2}=0.251\right)$, Taking part in decision-making $(\mathrm{F}(1,63)=44.724 ; p \leq 0.001$; $\left.\eta^{2}=0.419\right)$, Open relationship with employers/managers $(\mathrm{F}(1,63)=54.647 ; p \leq$ $\left.0.001 ; \eta^{2}=0.468\right)$, Accountability $\left(\mathrm{F}(1,63)=72.799 ; p \leq 0.001 ; \eta^{2}=0.540\right)$, Face concern $\left(\mathrm{F}(1,63)=70.608 ; p \leq 0.001 ; \eta^{2}=0.532\right)$ and Work-performance orientation vs. autocratic orientation $\left(\mathrm{F}(1,63)=28.087 ; p \leq 0.001 ; \eta^{2}=0.312\right)$. All differences can be seen a large difference (Cohen, 1988). The largest differences are seen for the work-related value of Being on time in a direct way $\left(\eta^{2}=0.774\right)$.

From the second multivariate analysis of variance, we see that Western employers also showed significantly higher scores on work-related values (Wilks' $\lambda$ $\left.(7,62)=6.657 ; p \leq 0.001 ; \eta^{2}=0.429\right)$, compared to Vietnamese employers. The 
Table 6. Means and standard deviations on the work-related values.

\begin{tabular}{|c|c|c|c|c|}
\hline & \multicolumn{2}{|c|}{ Western companies } & \multicolumn{2}{|c|}{ Vietnamese companies } \\
\hline & $\begin{array}{l}\text { Western employers } \\
\qquad(\mathrm{n}=47)\end{array}$ & $\begin{array}{l}\text { Vietnamese employees } \\
\qquad(\mathrm{n}=47)\end{array}$ & $\begin{array}{l}\text { Vietnamese employers } \\
\qquad(\mathrm{n}=38)\end{array}$ & $\begin{array}{c}\text { Vietnamese employees } \\
\qquad(\mathrm{n}=32)\end{array}$ \\
\hline & Mean (SD) & Mean (SD) & Mean (SD) & Mean (SD) \\
\hline \multicolumn{5}{|l|}{ Work-related values } \\
\hline Being on time in a direct way & $4.59(0.31)$ & $3.50(0.28)$ & $4.30(0.36)$ & $3.55(0.26)$ \\
\hline Being on time with a condition & $3.48(0.54)$ & $2.96(0.28)$ & $2.93(0.47)$ & $2.99(0.40)$ \\
\hline Taking part in decision-making & $4.06(0.28)$ & $3.40(0.46)$ & $3.93(0.36)$ & $3.25(0.46)$ \\
\hline Open relationship & $4.20(0.21)$ & $3.74(0.27)$ & $4.12(0.29)$ & $3.71(0.29)$ \\
\hline Accountability & $4.11(0.43)$ & $3.35(0.30)$ & $4.04(0.47)$ & $3.37(0.35)$ \\
\hline Face concern ${ }^{*}$ & $3.91(0.49)$ & $2.99(0.35)$ & $3.15(0.49)$ & $2.88(0.22)$ \\
\hline Work-performance orientation & $4.22(0.29)$ & $3.87(0.32)$ & $4.19(0.35)$ & $3.76(0.37)$ \\
\hline
\end{tabular}

Note. Open relationship = Open relationship with employers/manager; Work-performance orientation = Work-performance orientation versus Autocratic orientation. ${ }^{*}$ Face concern items have been recoded so that the higher the score, the lower the face concern.

test of between-subjects effects indicated that both groups differed significantly on three-related values with higher scores for Western employers on Being on time in a direct way $\left(\mathrm{F}(1,69)=12.467 ; p \leq 0.001 ; \eta^{2}=0.155\right)$, Being on time with a condition $\left(\mathrm{F}(1,69)=20.606 ; p \leq 0.001 ; \eta^{2}=0.233\right)$, and Face concern $(\mathrm{F}(1,69)$ $\left.=40.256 ; p \leq 0.001 ; \eta^{2}=0.372\right)$. All differences can be seen a large difference (Cohen, 1988), although considerably smaller than with the difference between Western employers and Vietnamese employees. The largest differences are seen for the work-related value of Face concern $\left(\eta^{2}=0.372\right)$. These findings mean that hypothesis 1 is confirmed.

The interview data gave additional insights and illustration of these findings. With respect to sense of time, scores of Western employers, on the hand, and Vietnamese employees and employers, on the other hand, were significantly different. In the interviews, the Western managers often blamed the Vietnamese employees for deadline tardiness and suppressing the truth about their lateness, whereas the Vietnamese employees confirmed that they have used their working time flexibly and that they should be more conscious of keeping the deadlines.

With respect to participation in decision-making, the Vietnamese employees seemed to be very positive when they can voice their ideas to the managers. A quotation of one of the employee interviewees illustrates the employees' feelings:

Compared to my former local companies, I have a voice here and I have been fairly treated. My employer always listens to my ideas and proposals. I can freely talk about my viewpoints. I am more open since I have been working in this company.

However, in the interviews, the Western employers showed their frustration, because they believed that the Vietnamese employees do not contribute many ideas for the working process as the following quotation of an employer inter- 
viewee illustrates:

I always encourage my employees to take their own decisions and correct their own mistakes. Vietnamese people tend to say "yes" all the time even when they do not understand anything, they still say "yes". I prefer people to say "no" and propose things to me. Vietnamese people do not take any strong decisions and always wait for the boss to make decisions for them. I always seek for advice from my staff because I am not perfect. I have to say that I spend lots of time and energy working with Vietnamese.

Concerning open relationships with the managers, some the Western managers criticized their Vietnamese employees to be very cold and to keep a great distance with their higher managers; yet, most of the local employees confirmed that they get along well with their employers, although some of them did say that they are afraid of their higher managers and keep a distance with them. In an interview, one of Western employers illustrated his employees' shyness:

I never close my door so that my employees can approach me any time when they have questions or problems. Opening the door signals my mental and physical openness to my employees. However, they rarely dare to reach me in my office. My employees should not over-respect me and should not keep the distance with me because of these over-respecting behaviors.

As showed above, the second largest difference between Western employers and Vietnamese employees was related to accountability. In the interviews, the Western employers complained that Vietnamese employees are not self-responsible in their work and need micromanagement most of the time. The Western managers were also concerned for their employees' lack of motivation to get promotion on their career. On the other hand, the Vietnamese employees confirmed that their employers seek for responsibility and accuracy from them. However, one employee showed her annoyance when her employer frequently that Vietnamese people lack self-accountability and usually need being directed. In the interviews, another employee mentioned: "My employer is a careful person and he always has judgement on the final product of his employees; thus he always demands us to work at our best. We have to adapt to his style a little bit". Another Vietnamese employee expressed her perception towards her employer's criticism about Vietnamese workers:

Another misunderstanding occurred when my boss usually said that we worked in a Vietnamese style. I disagreed with him and told him that you need cheap labor, then you came to Vietnam to work with us, the salary we received is much cheaper than it is in your country. Therefore, you should not criticize us in that way.

The third largest difference between Western employers and Vietnamese employees were related to the value of face concern. Scores on this work-related value showed the largest differences between Western and Vietnamese employers. In the interviews, the Vietnamese employees mentioned a preference for an open and direct communication style of their Western higher managers despite 
the fact that some of their managers showed irritation for their Vietnamese staff's indirectness in communication. The Vietnamese employees confided their employers' openness and directness in communication. In an interview, one Vietnamese employee reported:

She is very open and direct. When she disagrees, she tells us directly what she disagrees about. She can use many bad words to scold us but she always let us talk against her about what we are thinking. There are arguments but the purposes of those arguments are to solve the problems in a direct and constructive manner.

In the interviews, some of the Western employers mentioned their employees' indirectness in conversations due to their scare of face loss. One employer illustrated this as follows:

They just response "Yes yes or no no". Especially when they make mistakes, they always keep silent. In Vietnam, people concern a lot about losing face. People tend to say "yes" a lot to please the hearer. For instance, I asked my employees whether they finish their tasks, they always say "yes" to please me although they have not finished yet. I think it is also because of "loss of face" that makes people tend to say "yes". I am very direct and easy to get frustrated because Vietnamese people are not clear in their conversation. They tend to say lies but it is not their intention to lie. It is just because they did not understand and they did not know what to do but they don't dare to speak out.

Finally, differences between Western employers and Vietnamese employees were the smallest-though still significant and large-on the value of work-performance orientation. In the interviews, the Western managers demonstrated their disappointment for the local employees' lack of innovation, reluctance to new things, changes and challenges, whereas Vietnamese employees contended that their managers readily accept new things and help them to advance a lot in their profession.

Work-related values of Vietnamese employers and Vietnamese employees

To test the second hypothesis, multivariate analysis of variance has been performed with Vietnamese employers and employees. Vietnamese employers showed higher scores on work-related values (Wilks' $\lambda(7,68)=31.546 ; p \leq 0.001 ; \eta^{2}=$ 0.763 ), compared to Vietnamese employees. The test of between-subjects effects indicated that both groups differed significantly on six out of the seven work-related values with higher scores for Vietnamese employers on Being on time in a direct way $\left(\mathrm{F}(1,75)=110.665 ; p \leq 0.001 ; \eta^{2}=0.599\right)$, Taking part in decision-making $\left(\mathrm{F}(1,75)=60.941 ; p \leq 0.001 ; \eta^{2}=0.452\right)$, Open relationship with employers/managers $\left(\mathrm{F}(1,75)=37.628 ; p \leq 0.001 ; \eta^{2}=0.337\right)$, Accountability $(\mathrm{F}(1,75)$ $\left.=58.123 ; p \leq 0.001 ; \eta^{2}=0.442\right)$, Face concern $\left(\mathrm{F}(1,75)=9.821 ; p=0.002 ; \eta^{2}=\right.$ $0.117)$ and Work-performance orientation vs. autocratic orientation $(\mathrm{F}(1,75)=$ 32.241; $\left.p \leq 0.001 ; \eta^{2}=0.305\right)$. All differences except one can be seen a large difference (Cohen, 1988), although for some work-related values smaller compared to the differences between Western employers and Vietnamese employees. No significant differences were found for Being on time with a condition $(\mathrm{F}(1,75)=$ 
0.406; $p=0.526)$. These findings mean that hypothesis 2 is partly confirmed.

Work-related values of Vietnamese employees from Western companies and Vietnamese companies

To test the third hypothesis, multivariate analysis of variance has been performed with Vietnamese employees from Western and Vietnamese companies. Employees of Western companies showed higher scores on work-related values $\left(\right.$ Wilks' $\left.\lambda(7,566)=3.456 ; p=0.001 ; \eta^{2}=0.040\right)$, compared to employees of Vietnamese companies. The test of between-subjects effects indicated that both groups differed significantly on three work-related values with higher scores for employees of Western companies on Taking part in decision-making $(\mathrm{F}(1,573)$ $\left.=9.311 ; p \leq 0.002 ; \eta^{2}=0.016\right)$, Open relationship with employers/managers $\left(\mathrm{F}(1,573)=6.784 ; p \leq 0.010 ; \eta^{2}=0.012\right)$, and Face concern $(\mathrm{F}(1,573)=14.991$; $\left.p \leq 0.001 ; \eta^{2}=0.026\right)$. The test of between-subjects effects indicated that both groups differed significantly on one other work-related values with higher scores for employees of Vietnamese companies on Being on time with a condition ( $\mathrm{F}(1$, $\left.573)=4.071 ; p \leq 0.044 ; \eta^{2}=0.007\right)$. All differences can be seen a small or negligible difference (Cohen, 1988). No significance differences were found for Being on time in a direct way $(\mathrm{F}(1,573)=1.110 ; p=0.293), \operatorname{Accountability}(\mathrm{F}(1,573)$ $=0.197 ; p=0.657)$, and Work-performance orientation vs. autocratic orientation $(\mathrm{F}(1,573)=2.699 ; p=0.101)$. These findings mean that hypothesis 3 is largely confirmed.

\section{Discussion and Conclusion}

Differences in work-related values were examined between employees and employers in Western and Vietnamese companies in Vietnam. The findings from the questionnaire data indicated that Western employers displayed higher mean scores than Vietnamese employees in all seven work-related values. Significant differences were also found between Vietnamese employers and Vietnamese employees, with higher scores for Vietnamese employers in six work-related values, except for the value: being on time with a condition. However, these differences between Vietnamese employers and Vietnamese employees were generally smaller compared with the differences between Western employers and Vietnamese employees. Additionally, we found three significant differences between Western and Vietnamese employers: Being on time in a direct way, Being on time with a condition and Face-concern, with higher scores for Western employers. The fact that Being on time with a condition disappeared and Face concern is small in the multivariate analyses of variance between Vietnamese employers and Vietnamese employees, compared with the findings from Western higher managers and Vietnamese employees, might mean that the cultural differences in work-related values are the largest in these two values. In the multivariate analyses of variance for the Vietnamese employees from Western and Vietnamese companies, we only found a very few and small differences between the employees from two types of companies. Similarly, from the interviews, the 
results also indicate that sense of time and face-concern are the two biggest issues between Western and Vietnamese professionals.

\section{Sense of time}

Consistent with pertinent literature, this cross-cultural work-related value showed the largest difference between Western employers and Vietnamese employees and employers. The explanation for those findings could be based on time perception theory (Arman \& Adair, 2012; Kawar, 2012), in which the Westerners are clever in time management; their plans and schedules are clearly arranged to ensure that they commit their deadlines. As discussed, Vietnamese workers following Confucianism are not always on time and they often fall behind deadlines. Time extension at workplaces is quite common in Vietnam and people in organizations understand the situation and feel at ease with the stretching of time.

\section{Face concern}

Face concern was also found to be significantly different from Western employers compared to Vietnamese employees and employers. Western employers scored the highest, the Vietnamese employees the lowest, and the Vietnamese employers in the middle (the higher the score, the less the participants' concern about face). However, the Vietnamese employers' scores were closer to those of the Vietnamese employees' than those of the Western employers', which indicated that the Vietnamese employers scored much lower than the Western employers. There might be two reasons for the differences in these groups. Firstly, because of its high power distance score and the influence of Confucianism, Vietnamese society highly values status and formality (Hofstede, 1984, 2001). In organizations, the relationship between superiors and subordinates is clearly defined (Vuong, 2002). When Westerners are in the position of managers and Vietnamese professionals the post of employees, the latter would withhold their points of view in order to show respect to more senior colleagues. Secondly, in line with previous findings (Pham, 2012, 2014; Merkin, 2006), Vietnamese professionals who tend to be interdependent people and depend on social identity might withdraw their egos and benefits in order to save their own as well as others' face. Strictly speaking, in Vietnamese culture, face maintenance for both sides is more important than accomplishments (Pham, 2014). However, the Vietnamese employees working in Western companies showed higher scores on this work-related value than those of the Vietnamese employees in Vietnamese companies, which might mean that after some time working with the Western managers, these Vietnamese employees somehow adapted and slightly adjusted their attitudes, in line with Sam \& Berry (2010). These authors found that individuals might have large variations in psychological well-being and sociocultural competence in the process of acculturation.

\section{Limitations and directions for future research}

We would like to address some limitations of our work. The first limitation is that the Western employer participants in the current study are from different 
cultural backgrounds and they have various nationalities. They were grouped to make a comparison with Vietnamese employers and employees possible. Different categories of employers might score differently on the seven work-related values. However, the standard deviations of the scores of the Western participants were similar to the standard deviations of the scores of the Vietnamese groups of participants.

The second limitation of this study is the lack of a Western employee sample working in the same companies as the Vietnamese employees. As the Western employers both represent people from different cultures and hold the position of superiors, the results might be affected by two conditions. Consequently, it is difficult to determine whether the differences were due to cultural distance or position distance. Therefore, we tested differences for both pairs of participants (Western employers versus Vietnamese employees and Vietnamese employers versus Vietnamese employees). However, in the future, when there are more Westerners working as employees in Vietnam, this research can be validated by comparing employees from these two cultures in the same companies.

The third limitation is that there was not much negative information obtained from the Vietnamese employees. Imprinted by the culture, specifically power distance, the Vietnamese professionals usually hesitate to offer straight and downside information about their managers (Oetzel \& Ting-Toomey, 2003; Jacqui \& Tran, 2009; Pham, 2014). It might be that they did not straightly express their resentment. Even many Western managers pointed out that their Vietnamese employees do not show bad things out; they generally come to the managers with good news and when they face troubles, they just keep the information as secrets and solve the problems by themselves. Therefore, in order to catch the real image of their attitudes at workplaces, we used many probing questions. Further research may also use observational instruments to gain more behavioral examples from their workplaces.

\section{Implications}

The findings of this study indicated the main differences in work-related values between Western higher managers and Vietnamese employees, which might lead to problematic communication and misunderstanding in outsourcing companies and joint-ventures. One of the implications might be that pre-departure adaptation is a good preparation for expatriates' later adjustment and on-site training is significant for both the foreigners and host country nationals (Peltokorpi, 2010). It is crucial that the companies together with the universities play active roles in supplying those communicative cross-cultural training so that culture-based misunderstandings and negative stereotypes can be lessened.

Based on the findings of the current study, some implications for on-site training and coaching can be formulated, which actually might be useful for international companies all over the world. For example, both direct and indirect facework strategies should be used simultaneously in order "to lessen the blow of the direct communication that needs to be used to get points across" (Merkin, 
2006: p. 155). Accordingly, the Vietnamese employees might be more comfortable to shorten the distance, talk freely and contribute their opinions to the management process. Sense of time would also be an area for training and coaching. Strict measures to discipline employees' time and deadlines at workplaces such as finger sensor scanning or salary reductions might lead to negative effects. The employees might be on time and keep the deadlines. Yet, they might be annoyed and try to avoid the punishment by completing the tasks without fully devoting their energy to the company's benefits; as a result the quality of their work might be influenced. Therefore, both sides should compromise their time management in order to accomplish a deal satisfying the company's needs.

Finally, both the Western managers and Vietnamese employees can be trained to establish employees' work independence. The managers, as mentors, should scaffold this procedure. Following are some simple ways that some managers already used for scaffolding:

- Micromanaging the employees by observing their schedules and their work progress.

- Arranging two-way communication with the local employees via face-to-face meetings, phone calls or emails. With this kind of management, information can be updated and the employees can express in time their opinions and concerns and receive the feedback from the management. The employees themselves also found that two-way communication is very effective to work out the problems.

- Providing frequent professional training within the companies as a Human Resource Management strategy to train the employees to acquire not only necessary and useful skills for their profession, but also the skills to be independent in their work.

\section{Concluding Remarks}

The current study provides insight into the work-related values of Western employers, Vietnamese employers and Vietnamese employees in international companies. Large differences exist between Western and Vietnamese professionals in all values and in sense of time and face concern in particular. This study made contributions to the field of Human Resource Management, providing insights and assisting future expatriates coming to Vietnam to do business with Vietnamese professionals. Additionally, for preparing graduates in Vietnam who are going to work with Western professionals the findings of the current study suggest that merely teaching the language might not be sufficient for effective communication at the workplace; culture instruction along with language instruction in higher education seems to be necessary to improve the current situation.

\section{Conflicts of Interest}

The authors declare no conflicts of interest regarding the publication of this paper. 


\section{References}

Arman, G., \& Adair, C. K. (2012). Cross-Cultural Differences in Perception of Time: Implications for Multinational Teams. European Journal of Work and Organizational Psychology, 21, 657-680. https://doi.org/10.1080/1359432X.2012.662488

Bjorkman, I., \& Lu, Y. (1999). The Management of Human Resources in Chinese-Western Joint Ventures. Journal of World Business, 34, 306-324.

https://doi.org/10.1016/S1090-9516(99)00021-8

Cohen, J. (1988). Statistical Power Analysis for the Behavioural Sciences (2nd ed.). Hillsdale, NJ: Lawrence Erlbaum Associates.

Diem, T. T. (2013). The Effect of National Culture on the Labour Productivity of Cross-Border Mergers and Acquisitions (Unpublished Master Thesis). Denmark: Aarhus University.

Gelfand, M. J., Lim, B. C., \& Raver, J. L. (2004). Culture and Accountability in Organizations: Variations in Forms of Social Control across Cultures. Human Resource Management Review, 14, 135-160. https://doi.org/10.1016/j.hrmr.2004.02.007

He, R., \& Liu, J. (2010). Barriers of Cross-Cultural Communication in Multinational Firms: A Case Study of Swedish Company and Its Subsidiary in China. Halmstad: Halmstad School of Business and Engineering.

Hofstede, G. (1984). Cultural Dimensions in Management and Planning. Asia Pacific Journal of Management, 1, 81-99. https://doi.org/10.1007/BF01733682

Hofstede, G. (2001). Culture's Consequences: Comparing Values, Behaviors, Institutions and Organizations across Nations (2nd ed.). London: Sage.

Hofstede, G., \& Bond, M. H. (1988). The Confucius Connection: From Cultural Roots to Economic Growth. Organizational Dynamics, 16, 5-21. https://doi.org/10.1016/0090-2616(88)90009-5

House, R., Javidan, M., \& Dorfman, P. (2001). Project Globe: An Introduction. Applied Psychology: An International Review, 50, 489-505.

https://doi.org/10.1111/1464-0597.00070

Jacqui, H., \& Tran, Q. N. T (2009). Perceptions of Facework in International Students-International Student Advisor Interaction. In Proceeding Papers in ISANA International Education Association 20th International Education Association 20th International Conference. http://espace.library.uq.edu.au/view/UQ

Jariya, A. M. I. (2012). Western Cultural Values and Its Implications on Management Practices. South East Asian Journal of Contemporary Business, Economics and Law, 1, 61-70. http://www.seajbel.com

Kawar, T. I. (2012). Cross-Cultural Differences in Management. International Journal of Business and Social Science, 3, 105-111. http://www.ijbssnet.com

Kim, J. Y., \& Nam, S. H. (1998). The Concept and Dynamics of Face: Implications for Organizational Behavior in Asia. Organization Science, 9, 522-534. https://doi.org/10.1287/orsc.9.4.522

Kirkman, B. L., Kevin, B. L., \& Cristina, B. G. (2006). A Quarter Century of Culture's Consequences: A Review of Empirical Research Incorporating Hofstede's Cultural Values Framework. Journal of International Business Studies, 37, 285-320. https://doi.org/10.1057/palgrave.jibs.8400202

Le, T. C., Rowley, C., Truong, Q., \& Warner, M. (2007). To What Extent Can Management Practices Be Transferred between Countries? The Case of Human Resource Management in Vietnam. Journal of World Business, 42, 113-127. 
https://doi.org/10.1016/j.jwb.2006.11.005

Matic, J. L. (2008). Cultural Differences in Employee Work Values and Their Implications for Management. Management, 13, 93-104.

Merkin, S. R. (2006) Power Distance and Facework Strategies. Journal of Intercultural Communication Research, 35, 139-160. https://doi.org/10.1080/17475750600909303

Ngyuen, T. Q. T. (2015). The Influence of Traditional Beliefs on Vietnamese College Lecturers' Perceptions of Face. Journal of Education for Teaching, 41, 203-214. https://doi.org/10.1080/02607476.2015.1031542

Oetzel, J. G., \& Ting-Toomey, S. (2003). Face Concerns in Interpersonal Conflict: A Cross-Cultural Empirical Test of the Face Negotiation Theory. Communication Research, 30, 599-624. https://doi.org/10.1177/0093650203257841

Peltokorpi, V. (2010). Intercultural Communication in Foreign Subsidiaries: The Influence of Expatriates' Language and Cultural Competencies. Scandinavian Journal of Management, 26, 176-188. https://doi.org/10.1016/j.scaman.2010.02.003

Pham, T. H. N. (2012). Cultural Dimensions in Intercultural Communication and Implications for English Language Teaching. Journal of Science, 70, 171-180.

http://www.hueuni.edu.vn

Pham, T. H. N. (2014). The Impact of Third Party Presence on the Motivational Concerns Underlying Linguistic Politeness Behavior in English-Speaking Intercultural Contexts. Journal for the Study of English Linguistics, 2, 19-33.

https://doi.org/10.5296/jsel.v2i1.5833

Sagie, A., \& Aycan, Z. (2003). A Cross-Cultural Analysis of Participative Decision-Making in Organizations. Human Relations, 56, 453-473.

https://doi.org/10.1177/0018726703056004003

http://www.sagepublications.com

Sam, D. L., \& Berry, J. W. (2010). Acculturation: When Individuals and Groups of Different Cultural Backgrounds Meet. Perspectives on Psychological Science, 5, 472-481. https://doi.org/10.1177/1745691610373075

Tran, T. T. (2013). Limitation on the Development of Skills in Higher Education in Vietnam. Higher Education, 65, 631-644. https://doi.org/10.1007/s10734-012-9567-7

Tran, T. T. (2015). Is Graduate Employability the Whole-of-Higher-Education-Issue? Journal of Education and Work, 23, 207-227.

https://doi.org/10.1080/13639080.2014.900167

Truong, Q., \& Nguyen, T. V. (2002). Management Style \& Organizational Effectiveness in Vietnam. Research and Practice in Human Resource Management, 10, 36-55.

Truong, T. D., Hallinger, P., \& Sanga, K. (2017). Confucian Values and School Leadership in Vietnam: Exploring the Influence of Culture on Principal Decision Making. Educational Management Administration \& Leadership, 45, 77-100. https://doi.org/10.1177/1741143215607877

Venter, F. (2006). The Cultural Differences in Time and Time Management: A Socio-Demographic Approach. Acta Commercii, 6, 39-49.

https://doi.org/10.4102/ac.v6i1.89

http://www.actacommercii.co.za

Vuong, T. (2002). Management Style \& Organizational Effectiveness in Vietnam. Research and Practice in Human Resource Management, 10, 36-55.

http://www.curtin.edu.au

Wang, J., Wang, G. G., Ruona, W. E. A., \& Rojewski, J. W. (2007). Confucian Values and 
the Implications for International HRD. Human Resource Development International, 8, 311-326. https://doi.org/10.1080/13678860500143285

Wang, Y. M. (2009). The Relationship of the Cultural Dimensions of Power Distance, Individualism-Collectivism, and Face Concerns, and of Immigrant Status on the Conflict Communication Styles of Chinese Managers of ENZ Subordinates in the New Zealand Workplace (Unpublished Master Thesis). Auckland: Unitec University.

Weng, A. W. T. (2015). Communication at the International Workplaces: The Foreign Managers' Perspective. International Journal of Business and Management, 10, 82-91. https://doi.org/10.1080/13678860500143285 